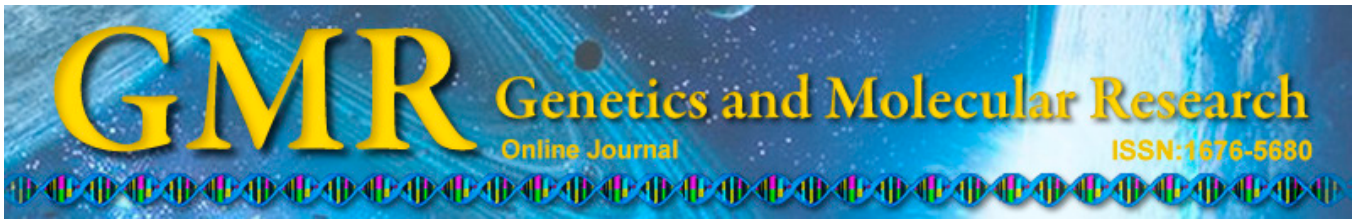

\title{
Evaluation of methods of DNA extraction from Staphylococcus aureus in milk for use in real-time PCR
}

\author{
A.G. Dibbern, B.G. Botaro, M.P. Viziack, L.F.P. Silva and M.V. Santos \\ Departamento de Nutrição e Produção Animal, \\ Faculdade de Medicina Veterinária e Zootecnia, Universidade de São Paulo, \\ Pirassununga, SP, Brasil
}

Corresponding author: M.V. Santos

E-mail: mveiga@usp.br

Genet. Mol. Res. 14 (1): 227-233 (2015)

Received May 8, 2014

Accepted September 11, 2014

Published January 16, 2015

DOI http://dx.doi.org/10.4238/2015.January.16.6

\begin{abstract}
The aim of this study was to evaluate the repeatability and performance of 4 methods of extracting DNA from Staphylococcus aureus (SAU) and the gene encoding bovine mitochondrial cytochrome $\mathrm{B}(\mathrm{BMCB})$ in milk samples from cows with subclinical mastitis for use in amplification by real-time polymerase chain reaction. Two milk samples were obtained from cows naturally infected with $S$. aureus and subjected to the following extraction methods: Qiagen DNA extraction kit; Axyprep DNA extraction kit; in silica column boil and in silica column method. After extraction in duplicate, eluates were subjected to purification and precipitation to determine purity $\left(\mathrm{A}_{260} / \mathrm{A}_{280}\right.$ ratio) and concentration ( $\mu \mathrm{g} /$ $\mu \mathrm{L}$ ) by spectrophotometry and amplification by real-time polymerase chain reaction of target genes ( $S A U$ and $B M C B)$. There was no effect of
\end{abstract}


the DNA extraction method on DNA concentration and threshold cycle for $B M C B$ and $S A U$. The purity ratio $\left(\mathrm{A}_{260} / \mathrm{A}_{280}\right)$ was higher when using Qiagen DNA extraction $(1.76 \pm 0.136)$ compared to the other methods tested. Our results indicate that the DNA extraction kit from Qiagen produces samples of the highest purity ratio compared to other methods.

Key words: DNA; Extraction; Mastitis; Staphylococcus aureus; Real-Time Polymerase Chain Reaction

\section{INTRODUCTION}

Bovine mastitis is considered an important illness in dairy cattle worldwide (Ribeiro et al., 2003), as it results in economic losses to the farmer (Bes et al., 2000) and dairies (Auldist and Hubble, 1998). Most disease cases have a bacterial etiology; therefore, it is necessary to identify the causative agent to adopt control and treatment measures (Oliver et al., 2004).

Isolation of the causative pathogen from intramammary infection in milk samples is considered the definitive diagnosis of bovine mastitis (Oliver et al., 2004). The conventional method for bacterial identification is based on the microbiology culture by phenotypic, biochemical, and enzymatic characteristics (Hogan et al., 1999). However, the microbiology culture of milking samples presents some limitations such as high analysis time an insufficient sensitivity to detect mammary quarters with intermittent elimination of Staphylococcus aureus in cases of subclinical mastitis (Phuektes et al., 2001; Taponen et al., 2009).

Because of the limitations of microbiology culture for mastitis diagnosis, qualitative protocols to detect pathogens based on polymerase chain reaction (PCR) have been described for microbial identification (Jayarao et al., 1991, Meiri-Bendek et al., 2002). Real-Time Polymerase Chain Reaction (qPCR) allows amplification and detection of the target gene to occur simultaneously in a closed system, from a coupled thermocycler to a monitoring system for fluorescence emission allowing for quantification of the number of DNA copies (Higuchi et al., 1993; Molina and Tobo, 2004). PCR is a rapid technique that allows the amplification of specific genome regions from minimal amounts of DNA, even if the DNA is degraded (Barea et al., 2004). The use of qPCR for detection of bovine mastitis-causing microorganisms shows diagnostic sensitivity and specificity similar to conventional qualitative methods of microbiological diagnosis (Taponen et al., 2009).

The qPCR method serves not only as a diagnostic means for pathogen detection (Koskinen et al., 2009; Taponen et al., 2009), but can also simultaneously quantify the target. However, qPCR still has had limited application for quantification of mastitis pathogen (Koskinen et al., 2009; Taponen et al., 2009), as the repeatability of results of quantification of the amplified target depends on the repeatability, quality, and yield, which is affected by the method used to extract genomic DNA (Mackay, 2004).

There is a strong demand for qPCR detection and enumeration of causative agents of bovine mastitis in milk samples. However, no previous study has determined which extraction methods produce the highest quality DNA with repeatability, absence of genomic DNA degradation, and genomic yield. Thus, the aim of this study was to evaluate genomic yield (DNA concentration), purity ( $\mathrm{A}_{260} / \mathrm{A}_{280}$ ratio), and repeatability of 4 methods used to extract DNA from $S$. aureus in milk samples from cows with subclinical mastitis. 


\section{MATERIAL AND METHODS}

Two composite milk samples were collected aseptically from dairy cows that had been positively diagnosed with $S$. aureus mastitis identified by microbiological culture, according to the method described by the National Mastitis Council (Hogan et al., 1999). The electronic somatic cell count in milk samples was performed by flow cytometry using the Somacount 300 (Bentley Instruments; Dublin, Ireland).

Four methods for extraction of bacterial genomic DNA were analyzed. Extractions were performed in duplicate accordingly using the method described below.

\section{Qiagen kit}

DNA extraction using a kit from Qiagen DNA isolation kit (Hilden, Germany) was performed according to manufacturer guidelines. In a microcentrifuge tube, $20 \mu \mathrm{L}$ Qiagen protease (or proteinase K) was pipetted into the bottom of the tube. Next, $200 \mu \mathrm{L}$ milk sample and $200 \mu \mathrm{L}$ lysis buffer (AL buffer) were added to the microcentrifuge tube. After homogenization by vortexing for $15 \mathrm{~s}$, the solution was incubated at $95^{\circ} \mathrm{C}$ for $10 \mathrm{~min}$. The solution was centrifuged to remove adhered contents inside the cap. Next, $200 \mu \mathrm{L}$ ethanol (96-100\%) was added and the sample was vortexed for $15 \mathrm{~s}$. The solution was centrifuged to remove adhered contents inside the cap. The solution was carefully transferred to a QIAamp mini spin column (in a 2-mL collection tube), followed by centrifugation at $6000 \mathrm{~g}$ for $1 \mathrm{~min}$. The mini spin column contents were transferred into a clean $2-\mathrm{mL}$ collection tube (supplied with the kit). After centrifugation, the collection tube with the filtrate was discarded. Next, $500 \mu \mathrm{L}$ wash buffer 1 (AW1 buffer) was added without wetting the tube edge. The solution was centrifuged at 6000 $g$ for $1 \mathrm{~min}$, after which the spin mini column was transferred to a new collection tube. The collection tube used was discarded. Again, $500 \mu \mathrm{L}$ wash buffer 2 (AW2 buffer) was added. The solution was then centrifuged at $20,000 \mathrm{~g}$ for $3 \mathrm{~min}$. After centrifugation, the solution was centrifuged for 1 min under the same conditions. The mini spin column was transferred to a new $1.5-\mathrm{mL}$ collection tube for recovery of extracted DNA, the used collection tube was discarded, and $100 \mu \mathrm{L}$ elution buffer (AE buffer) or distilled water was added. The solution was incubated at room temperature $\left(15^{\circ}-25^{\circ} \mathrm{C}\right)$ for $5 \mathrm{~min}$ and then centrifuged at $6000 \mathrm{~g}$ for 1 min. After centrifugation, the solution was centrifuged for 1 min under the same conditions. The extracted DNA was stored at $-20^{\circ} \mathrm{C}$.

\section{AxyPrep}

The protocol of the DNA extraction kit AxyPrep (Bacterial Genomic DNA Miniprep Kit protocol, Axygen Biosciences, Union City, CA, USA) was used after collecting $1.0 \times 10^{9}$ bacteria in a 2-mL microcentrifuge tube (supplied). The material collected was centrifuged at high speed $(20,000 \mathrm{~g})$ for $10 \mathrm{~min}$. The supernatant was discarded and the bacterial pellet was resuspended in $150 \mu \mathrm{L}$ bacterial preparation buffer (S buffer) containing RNAse. Next, $20 \mu \mathrm{L}$ lysozyme was added followed by stirring. The sample was incubated at room temperature for $15 \mathrm{~min}$, and then $30 \mu \mathrm{L} 0.25 \mathrm{M}$ EDTA, $\mathrm{pH}$ 8.0, was added and the sample was incubated on ice for $5 \mathrm{~min}$. After adding $450 \mu \mathrm{L}$ lysis buffer (GA buffer), the sample was homogenized by vortexing for $15 \mathrm{sec}$, heated in a water bath at $65^{\circ} \mathrm{C}$ for $10 \mathrm{~min}$, and then $400 \mu \mathrm{L}$ protein removal buffer (GB buffer) was added, followed by $1 \mathrm{~mL}$ partition buffer (DV buffer) (pre-chilled to 
$4^{\circ} \mathrm{C}$ ). Vigorous mixing was followed by centrifugation at $12,000 \mathrm{~g}$ for $2 \mathrm{~min}$. The upper layer of the solution (blue phase) was discarded without disturbing the interface. Next, $1 \mathrm{~mL}$ partition buffer (DV buffer) (pre-chilled to $4^{\circ} \mathrm{C}$ ) was added for the remainder of the interface and lower phase and mixed vigorously to achieve homogeneity. The sample was centrifuged at $12,000 \mathrm{~g}$ for $2 \mathrm{~min}$. The upper phase of the solution (blue color) was completely removed, with only the lower phase (clear coloration) of the solution remaining in the tube. The lower phase was transferred to a silica filter by placing it in a $2-\mathrm{mL}$ microcentrifuge tube followed by centrifugation at 12,000 $\mathrm{g}$ for $1 \mathrm{~min}$. The filtrate was discarded and $400 \mu \mathrm{L}$ digestion buffer (BV buffer) was added to the filtrate and homogenized by vortexing. The base of a suction vacuum pump was attached and the mixture transferred to an AxyPrep column. The vacuum source was turned on and adjusted to 25-30 inches $\mathrm{Hg}$. A total of $500 \mu \mathrm{L}$ wash buffer 1 (W1 buffer) were added to the AxyPrep column and filtered through a vacuum system. Next, $700 \mu \mathrm{L}$ wash buffer 2 (W2 buffer) was added along the wall of the AxyPrep column after buffer AW1 and again filtered using the vacuum system. The column was washed again with $700 \mu \mathrm{L}$ wash buffer 2 (W2 buffer) and the AxyPrep column was placed inside a 2-mL microcentrifuge tube and centrifuged at $12,000 \mathrm{~g}$ for $1 \mathrm{~min}$. The AxyPrep column was transferred to a clean $1.5-\mathrm{mL}$ microcentrifuge tube (supplied), and $100-200 \mu \mathrm{L}$ water or eluant was added to the center of the membrane to elute the DNA. The sample was incubated for $1 \mathrm{~min}$ at room temperature and then centrifuged at $12,000 \mathrm{~g}$ for $1 \mathrm{~min}$. The DNA samples were stored at $-20^{\circ} \mathrm{C}$.

\section{Silica column method}

Reagents and buffers used for the silica column method (adapted method from Cremonesi et al., 2006 using the silica column) and boil on silica column method (adapted Barea et al., 2004), were prepared based on the protocol described by Cremonesi et al. (2006). First, 0.5 M EDTA, $\mathrm{pH} 8.0,100 \mathrm{mM}$ Tris-HCl, $\mathrm{pH}$ 6.8, and $1 \mathrm{M}$ Tris-HCl, $\mathrm{pH} 8.0$, solutions were prepared. Next, lysis buffer (AL buffer) was prepared by adding $2 \mathrm{~g}$ Triton, $5 \mathrm{~mL} 100 \mathrm{mM}$ Tris-HCl, pH 6.8, 2 mL 0.5 M EDTA, 17.724 g guanidine thiocyanate (Sigma-Aldrich, St. Louis, MO, USA), $0.5 \mathrm{~g}$ DL.T, and $50 \mathrm{~mL}$ QSP MilliQ water. The washing buffers 1 and 2 (AW1 and AW2 buffers) were prepared by adding $0.146 \mathrm{~g} \mathrm{NaCl}, 6.25 \mathrm{~mL}$ absolute ethanol, $6.25 \mathrm{~mL}$ isopropanol, $8.862 \mathrm{~g}$ guanidine thiocyanate (Sigma-Aldrich), $250 \mu \mathrm{L} 1 \mathrm{M}$ Tris- $\mathrm{HCl}$, $\mathrm{pH} 8$, and $35 \mathrm{~mL}$ QSP MilliQ water. However, guanidine hydrochloride (Sigma-Aldrich) was not added to wash buffer 2 (AW2 buffer); instead, $25 \mathrm{~mL}$ QSP MilliQ water was used. The elution buffer (AE buffer) was prepared by adding $150 \mu \mathrm{L} 1 \mathrm{M}$ Tris-HCl, $\mathrm{pH}$ 8.0, $30 \mu \mathrm{L} 0.5 \mathrm{M}$ EDTA, and $15 \mathrm{~mL}$ QSP MiliQ water.

\section{Silica column boil}

For the silica column boil method (adapted method from Nogueira et al., 2004 using the silica column), $200 \mu \mathrm{L}$ sample and $200 \mu \mathrm{L}$ AW1 buffer were added to a microcentrifuge tube. After boiling at $95^{\circ} \mathrm{C}$ for $10 \mathrm{~min}$, the solution was transferred to a microcentrifuge silica tube and centrifuged at $6000 \mathrm{~g}$ for $1 \mathrm{~min}$. The filtrate resulting from the centrifugation was discarded. Next, $100 \mu \mathrm{L}$ AW2 buffer was added to the same microcentrifuge silica tube, which was again centrifuged at $20,000 \mathrm{~g}$ for $1 \mathrm{~min}$. The filtrate was again discarded. Another $100 \mu \mathrm{L}$ AW2 buffer was added and the tube was centrifuged at 20,000 $\mathrm{g}$ for $1 \mathrm{~min}$. The filtrate was again discarded. The bottom of the microcentrifuge tube was exchanged for final storage and 
$100 \mu \mathrm{L}$ AE buffer was added, then centrifuged at $6000 \mathrm{~g}$ for $1 \mathrm{~min}$. The centrifugation procedure was repeated and the filtrate reserved. DNA samples were stored at $-20^{\circ} \mathrm{C}$.

\section{Silica column}

For the silica column method, $180 \mu \mathrm{L}$ milk sample and $20 \mu \mathrm{L}$ proteinase $\mathrm{K}$ were mixed with $200 \mu \mathrm{L} \mathrm{AL}$ buffer, and the samples were heated at $70^{\circ} \mathrm{C}$ for $10 \mathrm{~min}$ to inactivate residual proteolytic activity. Next, $200 \mu \mathrm{L}$ ethanol were added, followed by $15 \mathrm{~s}$ of agitation. The resulting solution was transferred to a silica microcentrifuge tube and centrifuged at 6000 $g$ for $1 \mathrm{~min}$. The column was removed from the tube and placed into a clean tube. Addition of $500 \mu \mathrm{L}$ AW 1 buffer to column was followed by centrifugation at $6000 \mathrm{~g}$ for $1 \mathrm{~min}$. The wash procedure was repeated with the addition of $500 \mu \mathrm{L}$ AW2 buffer, followed by centrifugation at $20,000 \mathrm{~g}$ for $3 \mathrm{~min}$. Extracted DNA from the column was eluted by adding $100 \mu \mathrm{L}$ AE buffer. First, $50 \mu \mathrm{L}$ were added to the solution, and after $1 \mathrm{~min}$ of rest the tube was centrifuged at 6000 $g$ for $1 \mathrm{~min}$. The samples were transferred to a recovery tube, and then $50 \mu \mathrm{L} \mathrm{AE}$ buffer was again added to the solution. After a 5-min incubation, the tube was centrifuged at $6000 \mathrm{~g}$ for 1 min. DNA samples were stored at $-20^{\circ} \mathrm{C}$.

\section{Analysis}

After performing DNA extraction, samples were subjected to precipitation and purification procedures to determine DNA concentration using a spectrophotometer (Sambrook, 2000). To evaluate concentration and purity of extracted DNA, $7 \mu \mathrm{L}$ extracted sample was diluted in $63 \mu \mathrm{L} \mathrm{1X}$ Tris-HCl pH 8.0 EDTA buffer in spectrophotometer (GeneQuant ${ }^{\circledR}$ Pro; Amersham Biosciences; Florida, USA), to determinate the $\mathrm{A}_{260} / \mathrm{A}_{280}$ ratio and concentration of genomic material in units of $\mu \mathrm{g} / \mu \mathrm{L}$.

After extraction, samples were amplified by qPCR using the StepOne method (Applied Biosystems, Foster City, CA, USA) according to the manufacturer protocol. The primer for the positive control was based on the bovine mitochondrial cytochrome $\mathrm{B}$ (BMCB) gene, with sense 5'-GCAATACACTACACATCCGACACAA-3' and antisense 5'-GCGTGTATGTATCGGATGATTCAG-3', the primers for amplification reactions of $S$. aureus were, respectively, senso 5'-CCTGAAGCAAGTGCATTTACGA-3' e antisenso 5'-CTTTAGCCAAGCCTTGACGAACT-3', designed using the PrimerExpress software (Applied Biosystems). For the amplification reaction, the reaction mixture was composed of 10 $\mu \mathrm{L}$ SYBR Green PCR Master Mix, 3.6 $\mu \mathrm{L}$ sense and antisense primers, and $1.8 \mu \mathrm{L}$ autoclaved MilliQ water. Next, $1 \mu \mathrm{L}$ of each extracted DNA sample was added to $19 \mu \mathrm{L}$ reaction mixture into each well of an qPCR plate. The main primers used were BMCB (gene encoding bovine mitochondrial cytochrome B) and SAU (S. aureus). The thermocycler program was run for 50 cycles at $95^{\circ} \mathrm{C}$ for $15 \mathrm{~s}$ and $60^{\circ} \mathrm{C}$ for $1 \mathrm{~min}$, with an initial cycle of $95^{\circ} \mathrm{C}$ for $10 \mathrm{~min}$. After amplification, the results were expressed in threshold cycles $(\mathrm{Ct})$.

Results were subjected to descriptive statistics and analysis of variance using the Minitab software, version 16.1.1 (State College, PA, USA).

\section{RESULTS}

Treatment means were compared using the Tukey test with a significance level of 5\%. 
In this study, there was no effect of extraction method on $\mathrm{Ct}$ values and DNA concentration; however, there was an effect of the extraction method on the $\mathrm{A}_{260} / \mathrm{A}_{280}$ ratio (Table 1). The Qiagen method showed a higher purity ratio $\left(\mathrm{A}_{260} / \mathrm{A}_{280}\right.$ ratio $)$ of $1.76 \pm 0.136 \mu \mathrm{g} / \mu \mathrm{L}$ than the other extraction methods. The Axyprep, boiling, and silica column methods showed $\mathrm{A}_{260} / \mathrm{A}_{280}$ ratios of $1.36 \pm 0.064,1.33 \pm 0.057$, and $1.47 \pm 0.087 \mu \mathrm{g} / \mu \mathrm{L}$, respectively.

Table 1. Effect of DNA extraction method on DNA concentration $(\mu \mathrm{g} / \mu \mathrm{L}), \mathrm{A}_{260} / \mathrm{A}_{280}$ ratio, and threshold cycle.

\begin{tabular}{lcccccc}
\hline & Axyprep $^{\circledast}$ & Qiagen $^{\circledast}$ & Boil & Silica Column & SE & P value \\
\hline Concentration $\left.^{\circledR} \mu \mathrm{g} / \mathrm{mL}\right)$ & 449.25 & $414.1^{\mathrm{a}}$ & 330.75 & 626.50 & 177.1 & 0.184 \\
$\mathrm{~A}_{260^{\prime}} \mathrm{A}_{280}$ ratio & $1.36^{\mathrm{b}}$ & $1.76^{\mathrm{a}}$ & $1.33^{\mathrm{b}}$ & $1.47^{\mathrm{b}}$ & 0.182 & 0.021 \\
Threshold cycle $^{1}$ & 36.363 & 38.689 & 39.391 & 36.172 & 7.949 & 0.934 \\
Threshold cycle $^{2}$ & 19.385 & 19.305 & 23.225 & 24.130 & 4.044 & 0.249 \\
\hline
\end{tabular}

Means followed by the same letter in the same row do not differ at the $5 \%$ level according to the Tukey test. Threshold cycle ${ }^{1}$ represents Ct for SAU (Staphylococcus aureus) and Threshold cycle ${ }^{2}$ represents Ct for BMCB (gene encoding bovine mitochondrial cytochrome B).

Using the coefficient variation of purity $\left(\mathrm{A}_{260} / \mathrm{A}_{280}\right.$ ratio), all methods were shown to have lower values, or values close to $5 \%$, indicating good repeatability during amplification.

\section{DISCUSSION}

In a study by Lusk et al. (2013), the commercially available Qiagen extraction method showed the highest performance for threshold cycle $(\mathrm{Ct} \leq 31)$ among all tested methods for DNA extraction from milk samples. In the present study, $\mathrm{Ct}$ values were not affected by the extraction method used. The results of the present study are similar to those of Simonato et al. (2007), who showed higher amplification and purity of samples extracted using the Qiagen method. However, compared with other DNA extraction methods, such as Chelex and boiling, the cost of the Qiagen extraction method was higher (Barea et al., 2004; Simonato et al., 2007). The Axyprep method showed questionable repeatability; it showed variable results in eliminating the "supernatant" considering that the handler directly interferes with repeatability. The supernatant was derived from reagents of the extraction kit, with the milk fat forming a fat layer in the tube, preventing direct contact of the pipette tip with the liquid fraction of the sample without physically contacting the supernatant. The other extraction methods studied did not generate a fat layer (supernatant).

Replacement of the silica cap with a silica column for immediate use in the column silica method provides reliability, ease of use, and shorter execution time, compared to the original protocol using the silica cap, as described by Cremonesi et al. (2006).

Although the results were limited because only 2 samples were analyzed, the coefficients of variation in relation to the concentration methods were less than $5 \%$. One possible source of variation, as described by Phillips et al. (2012), may be pipetting errors during transfer of DNA into the wells of the qPCR plate; if a pipetted volume is reduced, less DNA is extracted from the sample. Another source of variation is the fat concentration present in milk samples, which directly interferes in the extraction of DNA from milk.

qPCR can be used to detect mastitis-causing agents, but the DNA extraction technique requires improvement. The $\mathrm{qPCR}$ technique is limited to detecting agents with purity values $\left(\mathrm{A}_{260} / \mathrm{A}_{280}\right.$ ratio) of 1.6-1.9, the possibility of repetition (coefficient of variation $<5 \%$ ), 
and quality and yield of genetic material, and the possibility of amplification by qPCR from a sample that has had a successful DNA extraction. The Qiagen DNA Isolation Kit method showed the highest purity (1.76), as well as high repeatability (coefficient of variation $<5 \%$ ). Thus, the DNA extraction kit from Qiagen showed the highest purity ratio compared with the other methods tested.

\section{ACKNOWLEDGMENTS}

Research supported by Fundação de Amparo à Pesquisa do Estado de São Paulo, FAPESP Process \#2010/10584-1.

\section{REFERENCES}

Auldist MJ and Hubble IB (1998). Effects of mastitis on raw milk and dairy products. Aust. J. Dairy Tech. 53: 28-36.

Barea JA, Pardini MIMC and Gushiken T (2004). Extração de DNA de materiais de arquivo e fontes escassas para utilização em reação de polimerização em cadeia (PCR). Rev. Bras. Hematol. Hemoter. 26: 274-281.

Bes M, Guerin-Faublee V, Meugnier H, Etienne J, et al. (2000). Improvement of the identification of staphylococci isolated from bovine mammary infections using molecular methods. Vet. Microbiol. 71: 287-294.

Cremonesi P, Castiglioini B, Malferrari G and Biunno I (2006). Improved method for rapid DNA extraction of mastitis pathogens directly from milk. J. Dairy Sci. 89: 163-169.

Higuchi R, Fockle C, Dollinger G and Watson R (1993). Kinetic PCR analysis: real-time monitoring of DNA amplification reactions. Biotechnology 11: 1026-1030.

Hogan JS, Gonzalez RN, Harmon RJ and Nickerson SC (1999). Laboratory Handbook on Bovine Mastitis. National Mastitis Council, Madison.

Jayarao BM, Dore JJ Jr., Baumbach GA, Matthews KR, et al. (1991). Differentiation of Streptococcus uberis from Streptococcus parauberis by polymerase chain reaction and restriction fragment length polymorphism analysis of 16S ribosomal DNA. J. Clin. Microbiol. 29: 2774-2778.

Koskinen MT, Holopainen J, Pyorala S, Bredbacka P, et al. (2009). Analytical specificity and sensitivity of a real-time polymerase chain reaction assay for identification of bovine mastitis pathogens. J. Dairy Sci. 92: 952-959.

Lusk TS, Strain E and Kase JA (2013). Comparison of six commercial DNA extraction kits for detection of Brucella neotomae in Mexican and Central American-style cheese and other milk products. Food Microbiol. 34: 100-105.

Mackay IM (2004). Real-time PCR in the microbiology laboratory. Clin. Microbiol. Infect. 10: 190-212.

Meiri-Bendek I, Lipkin E, Friedmann A, Leitner G, et al. (2002). A PCR-based method for the detection of Streptococcus agalactiae in milk. J. Dairy Sci. 85: 1717-1723.

Molina AL and Tobo PR (2004). Parte 2: uso das técnicas de biologia molecular para diagnóstico. Einstein 2: 139-142.

Nogueira CAM, Momesso CAS, Machado RLD and Almeida MTG (2004). Desempenho de kits comerciais e protocolos laboratoriais para a extração de DNA genômico bacteriano. Rev. Panam. Infectol. 6: 35-38.

Oliver SP, Gonzalez RN and Hogan JS (2004). Microbiological Procedures for the Diagnosis of Bovine Udder Infection and Determination of Milk Quality. National Mastitis Council, Madison.

Phillips K, McCallum N and Welch L (2012). A comparison of methods for forensic DNA extraction: Chelex-100(R) and the QIAGEN DNA Investigator Kit (manual and automated). Forensic Sci. Int. Genet. 6: 282-285.

Phuektes P, Mansell PD and Browning GF (2001). Multiplex polymerase chain reaction assay for simultaneous detection of Staphylococcus aureus and streptococcal causes of bovine mastitis. J. Dairy Sci. 84: 1140-1148.

Ribeiro MER, Petrini LA, Aita MF and Balbinotti M (2003). Relação entre mastite clínica, subclínica infecciosa e não infecciosa em unidades de produção leiteiras na região sul do rio grande do sul. Rev. Bras. Agroc. 9: 287-290.

Sambrook J (2000). Molecular Cloning: A Laboratory Manual. Cold Spring Harbor Laboratory Press, Cold Spring Harbor, New York.

Simonato LE, Garcia JF, Nunes CM and Miyahara GI (2007). Avaliação de dois métodos de extração de DNA de material parafixado para amplificação em PCR. J. Bras. Patol. Med. Lab. 43: 121-127.

Taponen S, Salmikivi L, Simojoki H and Koskinen MT (2009). Real-time polymerase chain reaction-based identification of bacteria in milk samples from bovine clinical mastitis with no growth in conventional culturing. J. Dairy Sci. 92 : 2610-2617. 